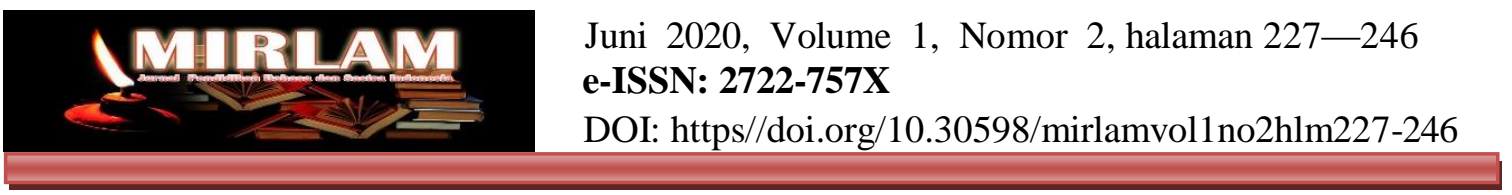

\title{
IMPLIKATUR PERCAKAPAN ANTARANGGOTA KOMUNITAS MERAH SAGA DI KOTA AMBON
}

\author{
Andi Nurlela \\ Romilda Arivina da Costa \\ Elsa Latupeirissa \\ Email : andinurlela18@gmail.com
}

\begin{abstract}
Abstrak: Penelitian implikatur percakapan ini berbentuk deskriptif kualitatif yang menggunakan metode observasi, wawancara, dan perekaman untuk mengumpulkan data. Analisis data dilakukan dengan menggunakan teori implikatur, tindak tutur, prinsip kerja sama, dan prinsip kesopanan. Hasil penelitian menunjukan adanya kehadiran implikatur baik dalam tuturan representatif, direktif, ekspresif, komisif, deklaratif, bahkan ada tuturan yang mengandung lebih dari satu implikatur pada satu konteks percakapan. Kehadiran implikatur pada tuturan menyebabkan sejumlah pelanggaran terhadap prinsip kerja sama. Pelanggaran dilakukan justru untuk memenuhi prinsip-prinsip kesopanan, terutama maksim relevansi.
\end{abstract}

Kata kunci: implikatur, tindak tutur, prinsip kesantunan, prinsip relevansi. 


\title{
IMPLIKATUR PERCAKAPAN ANTARANGGOTA KOMUNITAS MERAH SAGA DI KOTA AMBON
}

\author{
Andi Nurlela \\ Romilda Arivina da Costa \\ Elsa Latupeirissa \\ Email : andinurlela18@gmail.com
}

\begin{abstract}
This conversation implicature research is in the form of qualitative descriptive which uses observation, interview, and recording methods to collect data. Data analysis is done using implicature theory, speech acts, the principle of cooperation, and the principle of politeness. The results of the study show the presence of implicatures in representative, directive, expressive, commissive, declarative speech, and even utterances that contain more than one implicature in one context of conversation. The presence of implicatures in speech causes a number of violations of the principle of cooperation. Violations are carried out precisely to fulfill the principles of modesty, especially the maxim of relevance.
\end{abstract}

Keywords: implicature, speech act, politeness principle, principle of relevance. 


\section{A. PENDAHULUAN}

Bahasa sebagai alat penyampai maksud, tujuan dan keinginan seseorang kepada orang lain tidak jarang dituturkan oleh seseorang dengan struktur kalimat yang memiliki maksud terselubung atau tersembunyi. Tanpa disadari manusia seperti dituntut untuk memahami bukan hanya makna dari tuturan-tuturan yang diucapkan oleh mitra tutur, melainkan juga maksud-maksud yang turut digiring di dalam tuturan-tuturan tersebut berdasarkan konteks pertuturan. Persoalan seperti ini dikaji oleh linguistik pada tataran pragmatik yang memfokuskan pembahasannya pada fungsi bahasa dalam komunikasi, yakni fungsi deklaratif, representatif, ekspresif, direktif, dan komisif. Dalam menjalankan fungsi-fungsi tersebut, salah satu bentuk yang muncul adalah implikatur. Bentuk ini merupakan ungkapan yang menyiratkan sesuatu yang berbeda dengan yang sebenarnya diucapkan (Rohmadi, 2013: 9).

Fenomena implikatur percakapan sering dijumpai dalam komunikasi antar sesama pengguna bahasa untuk menyampaikan maksud dan tujuan, demikian pula yang terjadi dalam komunikasi antaranggota komunitas Merah Saga. Komunitas Merah Saga merupakan komunitas sastra yang dibentuk pada tahun 2012 melalui sebuah pementasan teaterikal yang mengusung tema perdamaian di monument Gong Perdamaian. Anggota komunitas ini berjumlah lebih dari 60 orang, yang sebagian besar merupakan mahasiswa. Sebagai pengguna bahasa, anggota komunitas ini tentunya memiliki berbagai peristiwa tutur yang tidak luput dari penggunaan implikatur dalam proses komunikasi. 
Istilah implikatur dipakai untuk menerangkan hal yang mungkin diartikan, disarankan, atau dimaksudkan oleh penutur yang berbeda dengan hal yang sebenarnya yang dikatakan oleh penutur (Brown dan Yule 1996: 31). Menurut Nababan (dalam Mulyana, 2005: 11) menyatakan bahwa implikatur berkaitan erat dengan konvensi kebermaknaan yang terjadi di dalam proses komunikasi. Konsep itu kemudian dipahami untuk menerangkan perbedaan antara hal "yang diucapkan" dengan hal "yang di implikasikan".

Kegunaan implikatur menurut Levinson (dalam Lubis, 2010: 73) antara lain, (1) dapat memberikan penjelasan makna atau fakta-fakta kebahasaan yang tak terjangkau oleh teori linguistik; (2) dapat memberikan penjelasan yang tegas tentang perbedaan lahiriah dari yang dimaksud si pemakai bahasa; (3) dapat memberikan pemerian semantik yang sederhana tentang hubungan klausa yang dihubungkan dengan kata penghubung yang sama; (4) dapat memberikan berbagai fakta yang secara lahiriah kelihatan tidak berkaitan, malah berlawanan (seperti metafora).

Pilihan kata atau diksi yang mengandung makna implisit dalam berkomunikasi antaranggota komunitas Merah Saga, yang dimaksudkan untuk menjaga kesantunan ternyata masih terus dibudayakan, meskipun tingkat keakraban yang terjalin antaranggota terbilang sangat dekat. Hal ini secara tegas menggambarkan bahwa era transparansi dan keakraban tidak mempengaruhi antaranggota untuk menyampaikan sesuatu secara transparan, tetapi justru disampaikan dengan bahasa yang santun agar tidak melukai perasaan seseorang. Selain itu, pilihan kata-kata puitis dalam berkomunikasi, yang memunculkan 
sejumlah implikatur percakapan antaranggota komunitas Merah Saga, sehingga penulis tertarik dan menganggap perlu untuk menganalisis fenomena implikatur tersebut melalui percakapan-percakapan yang berlangsung antaranggota komunitas Merah Saga di kota Ambon. Oleh karena itu, penelitian ini bertujuan untuk mendeskripsikan implikatur percakapan antaranggota Komunitas Merah Saga di Kota Ambon.

\section{B. METODE}

Pendekatan yang digunakan dalam penelitian ini adalah adalah pendekatan deskriptif kualitatif yang menggunkan metode observasi, wawancara dan perekaman untuk mengumpulkan data. Metode observasi digunakan untuk melakukan penjelajahan umum dan menyeluruh, melakukan deskripsi terhadap semua yang dilihat, didengar, dan dirahasiakan dengan berfokus pada kondisi dan situasi sosial yang meliputi tempat atau lokasi percakapan, pelaku yang telibat dalam percakapan, dan aktivitas yang dilakukan oleh para pelaku atau anggota komunitas pada saat percakapan berlangsung. Metode wawancara digunakan untuk menanyakan secara langsung hal-hal terkait data implikatur yang ditemukan, dengan harapan dapat menambah informasi, memperkuat interpretasi, serta mengkonfirmasi data implikatur yang ditemukan pada saat yang bersamaan. Sedangkan metode perekaman digunakan untuk merekam percakapan antaranggota komunitas Merah Saga, yang 
kemudian hasil rekaman tersebut ditranskripsikan untuk melengkapi informasi dan menginterpretasi makna yang terkandung dalam tuturan tersebut.

Selanjutnya keabsahan data penelitian ini diuji kredibilitasnya dengan teknik peningkatan ketekunan, diskusi dengan teman sejawat, dan triangulasi metode. Peningkatan ketekunan berarti peneliti melakukan pengamatan secara cermat dan berkesinambungan pada setiap aktivitas dan latihan rutin penulisan puisi yang dilakukan oleh anggota Komunitas Merah Saga. Diskusi dengan teman sejawat dilakukan dengan cara peneliti mengekspos hasil sementara atau hasil akhir yang diperoleh, dengan tujuan memperlihatkan persepsi, pandangan dan analisis yang sedang dilakukan. Dari informasi yang berhasil ditemukan diharapkan dapat memantapkan hasil penelitian. Triangulasi metode dilakukan dengan cara membandingkan informasi atau data dengan cara yang berbeda. Peneliti menggunakan metode wawancara dan observasi untuk memperoleh kebenaran dan gambaran utuh mengenai informasi tertentu. Selain itu, peneliti menggunakan informan yang berbeda untuk mengecek kebenaran informasi yang ditemukan.

Sejalan dengan pendekatan yang digunakan, analisis data dilakukan dengan memanfaatkan metode deskriptif kualitatif berdasarkan fenomena implikatur percakapan antaranggota komunitas merah saga di kota Ambon. Analisisnya data dilakukan dengan menggunakan teori implikatur, tindak tutur, prinsip kerja sama dan prinsip kesopanan. 


\section{PEMBAHASAN}

Dalam menganalisis implikasi pragmatis implikatur percakapan antaranggota komunitas Merah Saga, perlu diperhatikan panduan dari sudut pandang pendengar, sehingga dapat dinilai maksud dari setiap ucapan. Maksud implikatur percakapan antaranggota komunitas Merah Saga ditemukan daya ilokusi dan perlokusi dalam satuan pragmatis dengan implikasi yang bervariasi yaitu implikasi pragmatik representatif, direktif, ekspresif, komisif, dan deklarasi.

Selain itu, implakatur percakapan antaranggota komunitas Merah Saga juga ditemukan adanya kemunculan pertuturan yang menghasilkan lebih dari satu implikatur percakapan sekaligus dalam satu konteks tuturan antaranggota komunitas Merah Saga.

\section{Implikasi Pragmatis Representatif}

Implikatur percakapan dalam bentuk tuturan representatif pada umumnya berfungsi untuk mengatakan, menyatakan, melaporkan, memberikan informasi, membantah, menunjukan dan menyebutkan tentang sesuatu hal, seperti yang terjadi pada dialog dibawah ini.

Konteks: Percakapan terjadi saat seorang anggota komunitas (Vita) melihat temannya (Ama) yang sedang asik bermain gitar, padahal rapat komunitas sudah dimulai.
(A) Jay
: Nina, se kanal Iga?
(B) Nina
: Denyut dan nadi 
Representatif/memberikan informasi: percakapan tersebut terjadi di ruangan HMPS. Si (A) dan (B) sebelumnya sudah memiliki pengetahuan bersama terhadap pembicaraan yang dimaksudkan tersebut, yakni si (A) mengetahui dengan sangat baik, bahwa (B) berteman dengan orang yang disukainya yaitu Iga. Oleh karena itu, tuturan (A) yang dimaksudkan untuk menanyakan dan mengkonfirmasi informasi yang telah didapatkan oleh (A) sebelumnya. Mendengar pertanyaan (A), si (B) menuturkan kalimat denyut dan nadi, yang sebenarnya tidak dimaksudkan untuk sekedar mengatakan, justru dimaksudkan untuk memberikan informasi tentang kedekatan atau hubungan antara (B) dan temannya yang diungkapkan dengan kalimat denyut dan nadi, yang secara implisit menggambarkan hubungan mereka sangat dekat dan saling mengenal satu sama lain.

Data tersebut tergolong dalam tindak tutur langsung dengan memanfaatkan metafora karena terdapat kesesuaian modus tuturan dan fungsinya secara konvensional dan terdapat pemakaian kelompok kata bukan dengan arti yang sebenarnya, melainkan sebagai lukisan berdasarkan persamaan pada kalimat (denyut dan nadi) yang diumpamakan dengan kedekatan hubungan. Kelangsungan tersebut terkandung pada maksud tuturan (B) pada percakapan tersebut diungkapkan dengan modus kalimat deklaratif atau modus berita untuk menginformasikan sekaligus menunjukan kedekatan (B) dan temannya yang bernama Iga.

Dengan demikian, data tersebut memenuhi prinsip kesantunan Robin Lakoff pada skala kesekawanan karena nada tuturan dan sikap ramah dengan menganggap si (A) sebagai sahabat (B), yang ditujukan oleh (B) pada percakapan 
tersebut tidak terkesan angkuh, meskipun yang ditanyakan berpotensi menyinggung perasaan (B) karena sebelumnya (A) sudah mengetahui bahwa (B) dan Iga berteman, sehingga membuat (A) merasa nyaman, kerasan, serta merasa kesekawanan dan kesejajaran dalam peristiwa tutur tersebut.

\section{Implikasi Pragmatis Direktif}

Implikatur percakapan dalam bentuk tuturan direktif pada umumnya berfungsi untuk menyuruh/memerintah, memohon, menuntut, menyarankan, dan menantang mitra tutur tentang sesuatu hal yang terkandung dalam kalimat tersebut, seperti yang terjadi pada dialog dibawah ini.

Konteks: Percakapan terjadi pada saat evaluasi yang dilakukan pada saat malam ulang tahun Komunitas Merah Saga
(A) Ismi
: Beta kan batamang deng M. H. Hunubun, itu hampir setiap minggu tu dia posting dong pung kegiatan musikalisasi puisi. :

(B) Anggota $\quad$ (Terdiam dan menunduk) 
Direktif/menyuruh: percakapan terjadi pada saat evaluasi yang dilakukan pada malam ulang tahun Komunitas Merah Saga. Si (A) dan (B) sebelumnya sudah memiliki pengetahuan bersama terhadap pembicaraan yang dimaksudkan tersebut, yakni mereka mengetahui bahwa anggota Komunitas Merah Saga sudah sangat jarang mengadakan pertemuan, dan mengadakan kegiatan-kegiatan sastra. Oleh karena itu, tuturan (A) tidak dimaksudkan untuk sekedar mengatakan atau memberikan informasi, justru dimaksudkan untuk menyuruh (B) agar segera mengadakan pertemuan dan kegiatan-kegiatan sastra.

Data tersebut tergolong dalam tindak tutur tidak langsung karena terdapat ketidaksesuaian modus tuturan dan fungsinya secara konvensional. Ketidaklangsungan tersebut terkandung pada maksud tuturan (A) yang merupakan tuturan dengan modus berita atau deklaratif, dan maksud pengutaraannya mengandung ilokusi menyuruh.

Dengan demikian, data tersebut memenuhi skala kesantunan Leech pada skala tidak langsung karena tuturan (A) pada percakapan tersebut bersifat tidak langsung. Ketidaklangsungan tersebut terkandung pada maksud tuturan (A) yang merupakan tuturan dengan modus berita atau deklaratif, dan maksud pengutaraannya adalah menyuruh.

\section{Implikasi Pragmatis Ekspresif}

Implikatur percakapan dalam bentuk tuturan ekspresif pada umumnya berfungsi untuk memuji, mengucapkan terima kasih, mengkritik, menghina, meminta 
maaf, menyalahkan, mengejek, dan mengeluh tentang sesuatu hal yang dialami oleh penutur maupun mitra tutur, seperti yang terjadi pada dialog dibawah ini.

Konteks: Percakapan terjadi di samping Aula Universitas Pattimura, saat selesai pementasan anggota komunitas, pukul 17:00 WIT.

(A) Sasha : Tadi kamong pentas apa itu?

(B) Anto : Musikalisasi puisi ca.

(A) Sasha : Terlalu bagus, beta pulang periksa di dokter nanti.

Ekspresif/menghina: percakapan tersebut terjadi sesaat setelah pementasan musikalisasi puisi beberapa anggota komunitas Merah Saga. Si (A) dan (B) sebelumnya sudah memiliki pengetahuan bersama terhadap pembicaraan yang dimaksudkan tersebut, yakni (A) mengetahui dan (B) menyadari bahwa penampilan musikalisasi puisi yang baru saja ditampilkan sangat jauh dari kata cukup, karena (B) menampilkannya dengan tidak begitu baik, dan petikan gitarnya juga terjadi banyak kesalahan, serta masih banyak kekurangan lainnya. Oleh karena itu, tuturan (A) yang ditujukan untuk menjawab pernyataan dari (B) tidak dimaksudkan untuk memuji, justru dimaksudkan untuk mengkritik sekaligus menghina penampilan (B) dan teman-temannya yang dipentaskan tersebut. Menurut (A) pementasan musikalisasi puisi yang dipentaskan oleh (B) dan teman-temannya tersebut sangat buruk, dan dianggap dapat merusak gendang telinga karena suara dan irama yang dihasilkan sangat tidak enak didengar.

Data tersebut tergolong dalam tindak tutur tidak langsung tidak literal, karena tuturan (A) pada percakapan tersebut diutarakan dengan modus kalimat dan makna kalimat yang tidak sesuai dengan maksud yang hendak diutarakan. Tuturan 
tersebut dituturkan oleh (A) dengan modus memuji, dan maksud pengutaraannya adalah menghina. Si (A) dengan dengan nada tertentu mengutarakan kalimat terlalu bagus, beta pulang periksa di dokter nanti, yang makna kalimatnya yaitu untuk mengatakan bahwa penampilan musikalisasi puisi (B) sangat buruk dan dapat merusak gendang telinga, sehingga (A) harus menemui dokter untuk memeriksa telinganya.

Dengan demikian, data tersebut memenuhi skala kesantunan Leech pada skala tidak langsung karena tuturan (A) pada percakapan tersebut bersifat tidak langsung. Ketidaklangsungan tersebut terkandung pada maksud tuturan (A) yang merupakan tuturan dengan modus memuji, dan maksud pengutaraannya adalah menghina.

\section{Implikasi Pragmatis Komisif}

Implikatur percakapan dalam bentuk tuturan komisif pada umumnya berfungsi untuk berjanji, bersumpah, bernazar, menolak, menawari, dan mengancam tentang sesuatu hal yang akan dilakukan oleh penutur maupun mitra tutur, seperti yang terjadi pada dialog di bawah ini.

Konteks: Percakapan terjadi di Tambak Universitas Pattimura, pukul 16:20 WIT. Saat anggota berkumpul membicarakan naskah yang akan dipentaskan di hari ulang tahun komunitas.
(A) Darko
: Naskah baru sa jua.
(B) Farid : : Pattimura baru satu kali tampil tu 
Komisif/menolak: percakapan tersebut terjadi saat semua anggota komunitas berkumpul di Tambak Universitas Pattimura yang berlokasi di samping Fakultas Hukum Universitas Pattimura. Si (A) dan (B) sebelumnya sudah memiliki pengetahuan bersama terhadap pembicaraan yang dimaksudkan tersebut, yakni mereka mengetahui tujuan berkumpulnya seluruh anggota komunitas untuk membicarakan hal-hal terkait naskah yang akan dipentaskan pada saat milad atau ulang tahun komunitas Merah Saga. Oleh karena itu, tuturan (B) tidak dimaksudkan untuk sekedar memberikan informasi, justru dimaksudkan untuk menolak permintaan (A) untuk membuat naskah baru. Penolakan tersebut disampaikan dalam bentuk kalimat berita, untuk memberitahukan bahwa naskah pattimura baru satu kali dipentaskan. Sehingga secara tidak langsung tuturan (B) juga mengandung maksud agar (A) dan teman-temannya tetap mementaskan naskah tersebut.

Data tersebut tergolong dalam tindak tutur tidak langsung karena terdapat ketidaksesuaian modus tuturan dan fungsinya secara konvensional. Ketidaklangsungan tersebut terkandung pada maksud tuturan (B) yang merupakan tuturan dengan modus berita atau deklaratif, dan maksud pengutaraannya adalah menolak permintaan (A), dan perlokusinya yang diharapkan (A) dapat memikirkan dan memaklumi hal tersebut.

Dengan demikian, data tersebut memenuhi skala kesantunan Leech pada skala tidak langsung karena tuturan (B) pada percakapan tersebut bersifat tidak langsung. Ketidaklangsungan tersebut terkandung pada maksud tuturan (B) yang 
merupakan tuturan dengan modus berita atau deklaratif, dan maksud pengutaraannya adalah menolak.

\section{Implikasi Pragmatis Deklaratif}

Implikatur percakapan dalam bentuk tuturan ekspresif pada umumnya berfungsi untuk memutuskan, membatalkan, melarang, mengizinkan dan memberi maaf tentang sesuatu hal yang akan dilakukan oleh penutur maupun mitra tutur, seperti yang terjadi pada dialog dibawah ini.

Konteks: Percakapan terjadi di Taman Budaya Karang Panjang pukul 01:13 WIT, saat beberapa anggota komunitas pentas pada acara seni tersebut. Rahma yang ingin pulang karena sudah sangat lelah mengatakan.

(A) Rahma : Bang su bisa pulang?

(B) Revan : Menurut ale?

Deklarasi/melarang: percakapan tersebut terjadi di Taman Budaya Karang Panjang. Si (A) dan (B) sebelumnya sudah memiliki pengetahuan bersama terhadap pembicaraan yang dimaksudkan tersebut, yakni mereka mengetahui bahwa pementasan seni tersebut sudah berlangsung sampai tengah malam, yakni pukul 01:13 WIT. Selain itu, mereka juga mengetahui bahwa acara tersebut belum selesai, dan beberapa dari teman komunitasnya belum pentas. Si (A) yang sudah merasa sangat lelah menuturkan kalimat bang su bisa pulang?, yang dimaksudkan untuk 
bertanya kepada (B). Si (B) yang memahami maksud tuturan (A), langsung menuturkan Menurut ale?, yang sebenarnya tidak dimaksudkan untuk sekedar bertanya, justru dimaksudkan untuk malarang (A) untuk pulang, karena ada beberapa anggota komunitas yang belum pentas dan acara seninya juga belum selesai. Larangan tersebut disampaikan dalam bentuk kalimat pertanyaan, untuk membuat si (A) memikirkan kondisi dan hal yang tanyakan tersebut karena sebelumnya mereka sama-sama mengetahui bahwa pementasan seni tersebut sudah berlangsung sampai tengah malam, yakni pukul 01:13 WIT. Selain itu, mereka juga mengetahui bahwa acara tersebut belum selesai, dan beberapa dari teman komunitasnya belum pentas.

Data tersebut tergolong dalam tindak tutur tidak langsung karena terdapat ketidaksesuaian modus tuturan dan fungsinya secara konvensional. Ketidaklangsungan tersebut terkandung pada maksud tuturan (B) yang merupakan tuturan dengan modus tanya atau interogatif, dan maksud pengutaraannya adalah melarang.

Dengan demikian, data tersebut memenuhi skala kesantunan Leech pada skala tidak langsung karena tuturan (B) pada percakapan tersebut bersifat tidak langsung. Ketidaklangsungan tersebut terkandung pada maksud tuturan (B) yang merupakan tuturan dengan modus tanya atau interogatif, dan maksud pengutaraannya adalah melarang (A). 


\section{Implikasi Pragmatik yang Mengandung Lebih dari Satu Implikatur}

\section{Percakapan}

Berdasarkan hasil analisis dalam percakapan ternyata ditemukan adanya pertuturan berupa implikatur percakapan yang mengandung lebih dari satu implikatur percakapan antaranggota komunitas Merah Saga dalam satu konteks percakapan, seperti yang terjadi pada dialog dibawah ini.

Konteks: Percakapan terjadi di tempat kumpul (rumah Stain) saat pembahan tentang puisi romantis, Elma merasa sedikit kesulitan dalam membuat puisi romantis mengatakan:
(A) Elma
: Abang, beta seng bisa cipta puisi romantis.
(B) Ile : Se kan su ada di bumi.
(A) Elma
: (Terdiam) 
Percakapan tersebut terjadi di depan ruangan HMPS saat (A) mengadukan kesulitannya kepada (B) karena tidak mampu menuliskan puisi romantis. Si (A) dan (B) sebelumnya sudah memiliki pengetahuan bersama terhadap pembicaraan yang dimaksudkan tersebut, yakni si (A) sebelumnya telah disuruh oleh (B) untuk menciptakan puisi romantis, karena dirinya memiliki kelemahan dalam menciptakan puisi romantis.

Tuturan si (A) sebenarnya tidak dimaksudkan untuk sekedar memberikan informasi, tetapi juga dimaksudkan untuk meminta (B) mengganti permintaan dalam menciptakan puisi romantis karena ia sama sekali tidak bisa menciptakan puisi romantis. Hal tersebut dikarenakan selama ini (A) terbiasa menulis puisi yang bersifat sosial dan politik.

Si (B) yang memahami maksud tuturan si (A) langsung menuturkan kalimat se kan su ada di bumi, yang sebenarnya tidak dimaksudkan untuk sekedar memberikan informasi, tetapi juga untuk menyuruh (A) agar berlatih dengan serius dan sungguh-sungguh agar dirinya dapat menulis puisi dengan berbagai genre, terutama genre romantis. Karena menurut (B) kehadiran si (A) merupakan sebuah bentuk nyata dari cinta, dan cinta selalu menghadirkan hal-hal romantis. Meskipun demikian, keromantisan cinta tidak sebatas hubungan antar sepangan kekasih saja, tetapi bisa juga tentang orang tua, teman, dan bahkan sahabat. Jadi seharusnya (A) mampu menulis puisi romantis.

Data tersebut tergolong dalam tindak tutur tidak langsung, karena terdapat ketidaksesuaian modus tuturan dan fungsinya secara konvensional. 
Ketidaklangsungan tersebut terkandung pada maksud tuturan (A), yang merupakan tuturan dengan modus berita atau deklratif, dan maksud pengutaraannya adalah meminta, dan tuturan (B) yang merupakan tuturan dengan modus berita atau deklaratif, dan maksud pengutaraannya adalah menyuruh.

Dengan demikian, data tersebut memenuhi skala kesantunan Leech pada indirectnes scale atau skala tidak langsung karena tuturan (A) dan (B) pada percakapan tersebut bersifat tidak langsung. Ketidaklangsungan tersebut terkandung pada maksud tuturan (A) yang merupakan tuturan dengan modus berita atau deklaratif, dan maksud pengutaraannya adalah meminta, dan tuturan (B) yang merupakan tuturan dengan modus berita atau deklaratif, dan maksud pengutaraannya adalah menyuruh. Hal tersebut terimplikasikan dari tuturan (B) yang menggambarkan pemikiran (B) tentang kehadiran si (A) merupakan sebuah bentuk nyata dari cinta, dan cinta selalu menghadirkan hal-hal romantis. Meskipun demikian, keromantisan cinta tidak sebatas hubungan antar sepangan kekasih saja, tetapi bisa juga tentang orang tua, teman, dan bahkan sahabat. Jadi seharusnya (A) mampu menulis puisi romantis.

\section{KESIMPULAN}

Implikatur percakapan antaranggota Komunitas Merah Saga di Kota Ambon memunculkan lima jenis implikasi pragmatis, yakni (i) implikasi pragmatis representatif yaitu penutur menyatakan dan memberikan informasi yang bersifat umum dan ringkas kepada mitra tutur dengan menggunakan kalimat langsung dan 
memanfaatkan metafora yang disajikan dalam satuan pragmatis mengatakan dan memberikan informasi, (ii) implikasi pragmatis direktif yaitu penutur menyarankan, meminta, dan menyuruh mitra tutur untuk melakukan hal yang diinginkan penutur dengan menggunakan kalimat tidak langsung, kalimat tidak literal, dan tindak ilokusi yang disajikan secara tersirat dalam satuan pragmatis bertanya, mengatakan, dan menyuruhan dengan makna yang sebaliknya dari yang dituturkan oleh penutur, (iii) implikasi pragmatis ekspresif yaitu penutur mengkritik dan menghina hal yang dilakukan oleh mitra tutur dengan menggunakan kalimat tidak langsung, tidak literal, dan tidak langsung tidak literal yang disajikan secara tersirat dalam satuan pragmatis mengatakan dan memuji, (iv) implikasi pragmatis komisif yaitu penutur menolak dan mengancam mitra tutur dengan menggunakan kalimat tidak langsung, tidak langsung literal, dan tindak perlokusi yang disajikan secara tersirat dalam satuan pragmatis mengatakan, memberikan informasi, dan menyuruhan dengan makna yang sebaliknya dari yang dituturkan oleh penutur, (v) implikasi pragmatis deklarasi yaitu penutur melarang mitra tutur untuk melakukan hal yang diinginkannya dengan menggunakan kalimat tidak langsung yang disajikan secara tersirat dalam satuan pragmatis bertanya.

Selain itu, implikatur percakapan antaranggota Komunitas Merah Saga di kota Ambon juga ditemukan adanya kemunculan pertukaran tuturan yang menghasilkan lebih dari satu implikatur percakapan sekaligus dalam sebuah konteks tuturan implikatur percakapan.

Dalam pertukaran tuturan yang menghasilkan lebih dari satu implikatur percakapan penutur memberikan informasi, menawari, meminta, menyuruh, 
membantah, menolak, menyalahkan, dan menuntut mitra tutur melakukan hal yang dikatakan penutur dengan menggunakan kalimat tidak langsung yang disajikan secara tersirat dalam satuan pragmatis memberikan informasi, bertanya, mengatakan, menawari, dan memuji.

Implikatur percakapan antaranggota Komunitas Merah Saga di kota Ambon juga secara keseluruhan melanggar prinsip kerja sama terutama pada maksim relevansi, yaitu maksim yang mengharuskan setiap peserta percakapan memberikan kontribusi yang relevan dengan masalah pembicaraan. Pelanggaran terhadap maksim relevansi ternyata justru untuk memenuhi sejumlah maksim pada prinsip kesopanan atau kesantunan. Tujuan dari pemenuhan prinsip kesopanan atau kesantunan dalam percakapan antaranggota Komunitas Merah Saga adalah untuk menciptakan atau membangun keseimbangan sosial, keramahan hubungan dan menjaga keakraban antaranggota Komunitas Merah Saga.

\section{E. DAFTAR RUJUKAN}

Brown, Gillian dan George Yule. 1996. Analisis Wacana. Jakarta: Gramedia Pustaka Utama.

Lubis, Hamid Hasan. 2010. Analisis Wacana Pragmatik. Bandung: Angkasa Bandung.

Mulyana. 2005. Kajian Wacana Teori, Metode dan Prinsip-Prinsip Analisis Wacana.Yogyakarta: Tiara Wacana.

Rohmadu, Muhammad, Kundharu Sadhono dan Hastuti, 2013. Kajian Pragmatik. Surakarta: Yuma Pustaka. 